\title{
Effect of Heat Exposure on Gene Expression of Feed Intake Regulatory Peptides in Laying Hens
}

\author{
Zhigang Song, ${ }^{1}$ Lei Liu, ${ }^{1}$ Ardashir Sheikhahmadi, ${ }^{2}$ Hongchao Jiao, ${ }^{1}$ and Hai Lin ${ }^{1}$ \\ ${ }^{1}$ Department of Animal Science, Shandong Agricultural University, Taian, Shandong 271018, China \\ ${ }^{2}$ Department of Animal Science, Faculty of Agriculture, University of Kurdistan, Sanandaj 66177-15175, Iran
}

Correspondence should be addressed to Hai Lin, hailin@sdau.edu.cn

Received 6 December 2011; Revised 27 January 2012; Accepted 16 February 2012

Academic Editor: Dominic Fan

Copyright (C) 2012 Zhigang Song et al. This is an open access article distributed under the Creative Commons Attribution License, which permits unrestricted use, distribution, and reproduction in any medium, provided the original work is properly cited.

The aim of this paper was to investigate the effect of heat stress on the regulation of appetite-associated genes in laying hens. Forty eight laying hens were randomly divided into two circumstances: high $\left(31 \pm 1.5^{\circ} \mathrm{C}\right.$; relative humidity, $\left.82.0 \pm 2.2 \%\right)$ or normal $\left(20 \pm 2^{\circ} \mathrm{C}\right.$, control; relative humidity, $\left.60.1 \pm 4.5 \%\right)$ ambient environment. Heat stress decreased body weight gain $(P<0.01)$, feed intake $(P<0.01)$, laying rate $(P<0.05)$, average egg mass $(P<0.01)$, egg production $(P<0.01)$, shell thickness $(P<0.01)$, and feed efficiency $(P<0.05)$. High ambient temperature decreased plasma uric acid $(P<0.05)$. Heat stress significantly increased mRNA levels of ghrelin and cocaine- and amphetamine-regulated transcript $(P<0.05)$ and decreased mRNA levels of cholecystokinin $(P<0.05)$ in the hypothalamus. Heat stress significantly increased $(P<0.05)$ mRNA levels of ghrelin in the glandular stomach and jejunum but significantly decreased $(P<0.05)$ mRNA levels of cholecystokinin in the duodenum and jejunum. In conclusion, heat stress plays a unique role in some special neuropeptides (e.g., ghrelin, cocaine- and amphetamine-regulated transcript, and cholecystokinin), which might participate in the regulation of feed intake in laying hens under high ambient temperature.

\section{Introduction}

Over the last three decades, many researchers have studied the regulation of food intake in birds and mammals. Some peptide hormones, for instance, neuropeptide Y (NPY), melanin-concentrating hormone $(\mathrm{MCH})$, growth hormone releasing factor (GRF), and ghrelin, regulate appetite in mammals and birds. Feeding and energy homeostasis are fundamental actions necessary for survival [1]. In birds, the hypothalamus plays a pivotal role in integrating external environmental cues (especially for stressors) and generates the appropriate responses to influence feed intake [2]. Laying hens undergo various environmental stresses, including high/low temperature, which may last for a few hours, several days, or weeks. The hypothalamic-pituitary-adrenal (HPA) axis plays an integral role in the maintenance of homeostasis during stress. As suggested by Brobeck [3], hypothalamic neurons can perceive the increases in body temperature and exert an inhibiting influence on cells that are responsible for controlling feed intake.

The feed intake of laying hens decreases when the environmental temperature increases [4]. Stockland and Blaylock [5] reported lower feed intake and egg production in pullets reared under elevated temperatures. The suitable temperature for poultry is between $16^{\circ} \mathrm{C}$ and $25^{\circ} \mathrm{C}$ [6]. It has been estimated that for every $1{ }^{\circ} \mathrm{C}$ increase in temperature between $21^{\circ} \mathrm{C}$ and $30^{\circ} \mathrm{C}$, appetite decreases by $1.5 \%$, and for every $1^{\circ} \mathrm{C}$ increase in temperature between $32^{\circ} \mathrm{C}$ and $38^{\circ} \mathrm{C}$, the reduction is about $4.6 \%$ [7]. The heat production of birds decreases with lower feed consumption under high ambient temperature. While a number of reports have documented the effects of heat stress on the feed intake of chickens [8], the underlying neuroendocrine mechanism is virtually unknown. The objective of the present study was to investigate the effect of heat stress on gene expression of brain-gut peptides in the hypothalamus and gastrointestinal tract of laying hens. 


\section{Material and Methods}

2.1. Animal Management and Sample Collection. Eighty hens (Hy-line brown, 24 weeks of age) were raised in the same condition for two weeks before heat exposure. The hens were provided a diet with $16 \%$ crude protein and $11.3 \mathrm{MJ} / \mathrm{kg}$ of metabolisable energy. A light regime of 16 (light)/8 (dark) was applied. The study was approved by the Shandong Agricultural University and carried out in accordance with the "Guidelines for Experimental Animal" of Ministry of Science and Technology (Beijing, P. R. China).

Forty-eight laying hens with similar body weight [BW, $(1.65 \pm 0.12) \mathrm{kg}$ ] were selected and evenly distributed in 8 pens. The hens were randomly subjected to one of two treatments for $7 \mathrm{~d}$ : (1) high ambient environment $\left(31 \pm 1.5^{\circ} \mathrm{C}\right.$, heat-exposed; relative humidity, $82.0 \pm 2.2 \%$ ) or (2) normal temperature $\left(20 \pm 2^{\circ} \mathrm{C}\right.$, control; relative humidity, $60.1 \pm$ $4.5 \%)$. All the laying hens were assigned to normal temperature and fasted for $12 \mathrm{~h}$ before sampling.

After day 7 (morning of the eighth day), the laying hens were restrained and a blood sample was drawn from the wing vein within $30 \mathrm{~s}$ using a heparinized syringe and collected in ice-cold tubes $(09: 00 \mathrm{H}$ to $10: 00 \mathrm{H})$. Plasma was obtained after centrifugation at $400 \times \mathrm{g}$ for $10 \mathrm{~min}$ at $4^{\circ} \mathrm{C}$ and stored at $-20^{\circ} \mathrm{C}$. The plasma was further analysed for glucose, insulin, cholesterol (Chol), triiodothyronine $\left(\mathrm{T}_{3}\right)$, corticosterone (CORT), nonesterified fatty acid (NEFA), triglyceride (TG), and uric acid (UA). Hens were sacrificed by exsanguination [9] immediately after the blood samples were obtained. Then tissue samples of the hypothalamus, glandular stomach, duodenum, jejunum, and ileum were collected. The tissue samples were stored at $-80^{\circ} \mathrm{C}$ after snap-frozen in liquid nitrogen.

2.2. Production Performance and Egg Quality. The number of eggs, egg weight, BW, and feed intake were recorded daily during the experiment. The feed conversion ratio (feed/egg; FCR), laying rate, average egg mass, and egg production were calculated based on the data recorded.

At the end of the experiment, random samples of three eggs from each pen (12 eggs per treatment) were collected at random. Shell thickness was measured using a micrometre caliper, and the mean value of measurements at three locations (i.e., air cell, equator, and sharp end) on the egg was calculated [10].

2.3. Plasma Metabolites and Hormones. Plasma concentrations of glucose (F006, intra-assay coefficient of variation $2.25 \%)$, UA (C012, intra-assay coefficient of variation $2.1 \%$ ), TG (F001-1, intra-assay coefficient of variation 2.6\%), Chol (F002-2, intra-assay coefficient of variation 2.9\%), and NEFA (A042, intra-assay coefficient of variation 6.9\%) were measured spectrophotometrically using commercial diagnostic kits (Jiancheng Bioengineering Institute, Nanjing, P. R. China).

Plasma insulin level was measured by radioimmunoassay using guinea pig antiporcine insulin serum $(3 \mathrm{~V}$ Bio-engineering Group Co., Weifang, P. R. China). In this assay,
${ }^{125}$ I-labeled porcine insulin competed with chicken insulin for sites on the insulin-porcine antibody immobilised to the wall of a polypropylene tube. A large cross-reaction was observed between chicken insulin and the guinea pig anti-porcine serum [11]. The insulin used in this study was referred to as immune-reactive insulin. The sensitivity of the assay was $1 \mu \mathrm{IU} / \mathrm{mL}$, and all samples were included in the same assay to avoid interassay variability. An intra-assay coefficient of variation was $1.98 \%$.

Plasma CORT was measured using a sensitive and highly specific RIA kit (IDS Inc, Boldon, UK) with a sensitivity of $0.39 \mathrm{ng} / \mathrm{mL}$. These kits have been used in a previous study [12] and have low cross-reaction with aldosterone $(0.20 \%)$, cortisol $(0.40 \%)$ and deoxycorticosterone $(3.30 \%)$. To inactivate CORT-binding proteins, plasma samples were heated to $80^{\circ} \mathrm{C}$ for $10 \mathrm{~min}$ before the assay. The intra-assay variability was $3.8 \%$.

Thyroid hormone levels were measured by radioimmunoassay according to the method described by Darras et al. [13]. Briefly, $\mathrm{T}_{3}$ amounts were measured using a commercially available $\mathrm{T}_{3}$ antiserum from Byk-Sangtec (BykSangtec Diagnostica GmbH, Dietzenbach, Germany) in combination with a specific tracer (Amersham International, Slough, England). The intra-assay coefficient of variation was $4.5 \%$.

2.4. RNA Isolation and Analysis. Expression of genes in the hypothalamus, glandular stomach, duodenum, jejunum, and ileum was quantified using quantitative real-time PCR with SYBR Green I labeling.

Total RNA was isolated using the guanidinium isothiocyanate method with Trizol Reagent (Invitrogen, San Diego, CA, USA). The quality of RNA was tested by electrophoresis on an agarose gel and its quantity was determined using a biophotometer (Eppendorf, Germany).

RT reactions $(10 \mu \mathrm{L})$ consisted of $500 \mathrm{ng}$ total RNA, $5 \mathrm{mmol} / \mathrm{L} \mathrm{MgCl}_{2}, 1 \mu \mathrm{L}$ RT buffer, $1 \mathrm{mmol} / \mathrm{L} \mathrm{dNTP}, 2.5 \mathrm{U}$ AMV, $0.7 \mathrm{nmol} / \mathrm{L}$ oligo $\mathrm{d}(\mathrm{T})$, and $10 \mathrm{U}$ ribonuclease inhibitor (TaKaRa Biotechnology, Co., Ltd. Dalian, P. R. China). Realtime PCR analysis was conducted using the Applied Biosystems 7500 Real-time PCR System (Applied Biosystems, Foster, CA, USA). Each RT-reaction served as a template for a $20 \mu \mathrm{L}$ PCR reaction containing $0.2 \mu \mathrm{mol} / \mathrm{L}$ of each primer and SYBR green master mix (Takara Biotechnology, Co., Ltd., Dalian, P. R. China). Primer-set sequences are described in Table 1. Real-time PCR was predenatured at $95^{\circ} \mathrm{C}$ for $10 \mathrm{~s}$, followed by 40 cycles. Each cycle consisted of denaturation at $95^{\circ} \mathrm{C}$ for $5 \mathrm{~s}$ and annealing and extension at $60^{\circ} \mathrm{C}$ for $40 \mathrm{~s}$. At the end of each cycle, SYBR green fluorescence was detected to monitor the amount of PCR product. A standard curve was plotted to determine the fold dilutions during calculation of the efficiency of qPCR primers.

The relative amount of mRNA present in the gene was calculated according to the method of Livak and Schmittgen [14]. The mRNA levels of these genes were normalised to glyceraldehyde-3-phosphate dehydrogenase (GAPDH) levels $(\Delta \mathrm{CT}) . \Delta \mathrm{CT}$ was calibrated against the average of the control. The linear amount of target molecules relative to 
TABLE 1: Gene-specific primers used in the analysis of gene expression.

\begin{tabular}{|c|c|c|c|c|}
\hline Gene & GenBank accession no. & Primer sequences $\left(5^{\prime}-3^{\prime}\right)$ & Orientation & Product size $(\mathrm{bp})$ \\
\hline \multirow{2}{*}{ GAPDH } & \multirow{2}{*}{ NM_204305 } & ACATGGCATCCAAGGAGTGAG & Forward & \multirow{2}{*}{266} \\
\hline & & GGGGAGACAGAAGGGAACAGA & Reverse & \\
\hline \multirow{2}{*}{ NPY } & \multirow{2}{*}{ M87294 } & TGCTGACTTTCGCCTTGTCG & Forward & \multirow{2}{*}{148} \\
\hline & & GTGATGAGGTTGATGTAGTGCC & Reverse & \\
\hline \multirow{2}{*}{ AgRP } & \multirow{2}{*}{ NM_001031457 } & GGAACCGCAGGCATTGTC & Forward & \multirow{2}{*}{163} \\
\hline & & GTAGCAGAAGGCGTTGAAGAA & Reverse & \\
\hline \multirow{2}{*}{$\mathrm{CRH}$} & \multirow{2}{*}{ NM_001123031 } & CTCCCTGGACCTGACTTTCC & Forward & \multirow{2}{*}{86} \\
\hline & & TGTTGCTGTGGGCTTGCT & Reverse & \\
\hline \multirow{2}{*}{ Ghrelin } & \multirow{2}{*}{ AB075215 } & CCTTGGGACAGAAACTGCTC & Forward & \multirow{2}{*}{203} \\
\hline & & CACCAATTTCAAAAGGAACG & Reverse & \\
\hline \multirow{2}{*}{ POMC } & \multirow{2}{*}{ NM_001031098 } & CGCTACGGCGGCTTCA & Forward & \multirow{2}{*}{88} \\
\hline & & TCTTGTAGGCGCTTTTGACGAT & Reverse & \\
\hline \multirow{2}{*}{ CART } & \multirow{2}{*}{ BI394769 } & CCGCACTACGAGAAGAAG & Forward & \multirow{2}{*}{146} \\
\hline & & AGGCACTTGAGAAGAAAGG & Reverse & \\
\hline \multirow{2}{*}{ CCK } & \multirow{2}{*}{ NM_001001741 } & CAGCAGAGCCTGACAGAACC & Forward & \multirow{2}{*}{121} \\
\hline & & AGAGAACCTCCCAGTGGAACC & Reverse & \\
\hline \multirow{2}{*}{ MCR-4 } & \multirow{2}{*}{ NM_001031514 } & АСАСТССАGССТСТССАТТTСТ & Forward & \multirow{2}{*}{101} \\
\hline & & TGTTCATAGCAGCCTCCCGA & Reverse & \\
\hline \multirow{2}{*}{ MCR-1 } & \multirow{2}{*}{ AY220305 } & CACCTACTACCGCAACAACG & Forward & \multirow{2}{*}{218} \\
\hline & & AGCAGATGAAGAAGACTCCCAG & Reverse & \\
\hline \multirow{2}{*}{ MCR-5 } & \multirow{2}{*}{ AB012868 } & ТССАТТСТТССТССАТСТСАТСС & Forward & \multirow{2}{*}{157} \\
\hline & & CTTCCTCATTTCCTGGCTACG & Reverse & \\
\hline
\end{tabular}

TABLE 2: Laying hens' productive performance.

\begin{tabular}{lccc}
\hline & Control & Heat stress & $P$ value \\
\hline BW change (g/hen) & $47.54 \pm 7.39^{\mathrm{a}}$ & $-150.54 \pm 8.87^{\mathrm{b}}$ & $<0.001$ \\
Feed intake (g/hen/day) & $111.02 \pm 11.58^{\mathrm{a}}$ & $58.12 \pm 3.23^{\mathrm{b}}$ & 0.005 \\
Laying rate (\%) & $95.83 \pm 2.03^{\mathrm{a}}$ & $89.29 \pm 1.19^{\mathrm{b}}$ & 0.032 \\
Average egg mass (g) & $56.06 \pm 0.88^{\mathrm{a}}$ & $50.56 \pm 0.31^{\mathrm{b}}$ & \\
Egg production (g/hen/day) & $53.70 \pm 0.79^{\mathrm{a}}$ & $45.24 \pm 0.63^{\mathrm{b}}$ & $<.001$ \\
Shell thickness $(\mathrm{mm})$ & $0.38 \pm 0.01^{\mathrm{a}}$ & $0.32 \pm 0.01^{\mathrm{b}}$ & $<0.001$ \\
Feed/egg $(\mathrm{g} / \mathrm{g})$ & $2.07 \pm 0.22^{\mathrm{a}}$ & $1.29 \pm 0.08^{\mathrm{b}}$ & 0.016 \\
\hline
\end{tabular}

${ }_{\mathrm{a}, \mathrm{b}}$ Means in the same line with different superscript differ significantly, $P<0.05$; Values indicate mean \pm SEM. For feed intake, BW change, laying rate, egg production, and feed/egg analyses, $n=4$ /treatment; for shell thickness, $n=12$.

the calibrator was calculated by $2^{-\Delta \Delta C T}$. Therefore, all gene transcription results are reported as an $\mathrm{n}$-fold difference relative to the calibrator. The specificity of the amplification product was verified by melting curve and gel electrophoresis analysis.

2.5. Statistical Analyses. Data are presented as mean \pm SEM/ SE. For feed intake analysis, $n=4 /$ treatment; for shell thickness analysis, $n=12$; for plasma metabolite and hormone analyses, $n=8 /$ treatment; for all enzyme mRNA analyses, $n=6$. The homogeneity of variances among groups was confirmed using Bartlett's test. All data were subjected to oneway ANOVA analysis to test the main effect of the treatment. When the main effect of treatment was significant, differences between means were assessed using Duncan's multiple range analysis. $P<0.05$ was considered significant.

\section{Results}

3.1. Zootechnical Performance. Heat exposure resulted in a significant decrease $(P<0.05)$ in BW gain, feed intake, laying rate, average egg mass, egg production, shell thickness, and the feed/egg ratio (Table 2 ).

3.2. Plasma Metabolites and Hormone Levels. No significant difference $(P>0.05)$ was observed in plasma levels of CORT, glucose, insulin, NEFA, TG, and Chol, but plasma UA was significantly decreased $(P<0.05)$ (Figure 1$)$ with heat exposure.

3.3. Expression of Feed Intake Regulatory Peptides in Hypothalamus. Gene expression of NPY, pro-opiomelanocortin (POMC), agouti-related protein (AgRP), corticotropinreleasing hormone (CRH), melanocortin 1 (MCR-1), 


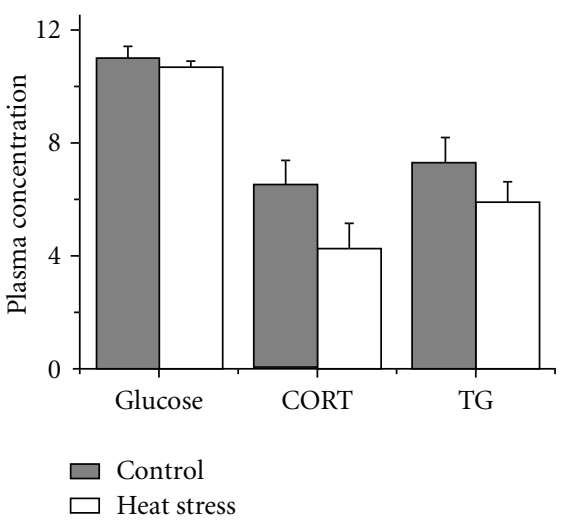

(a)

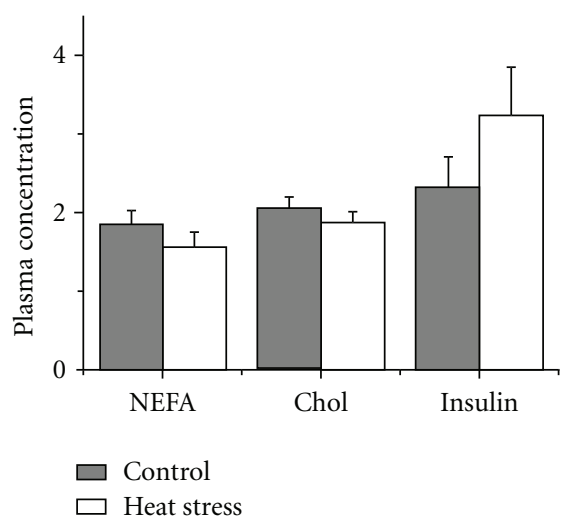

(b)

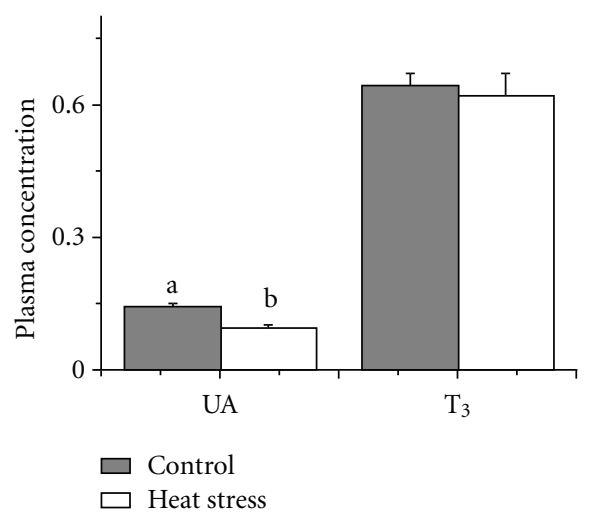

(c)

FigURE 1: Effect of heat stress on plasma parameters in laying hens. (a) Glucose ( $\mathrm{mmol} / \mathrm{L})$, triglyceride (TG, mmol/L), and corticosterone (CORT, ng/mL); (b) Insulin ( $\mu \mathrm{IU} / \mathrm{mL})$, nonesterified fatty acid (NEFA, mmol/L), and cholesterol (Chol, $\mu \mathrm{mol} / \mathrm{L})$; (c) Uric acid (UA, $\mathrm{mmol} / \mathrm{L}$ ) and triiodothyronine $\left(\mathrm{T}_{3}, \mathrm{ng} / \mathrm{mL}\right)$. Values indicate mean \pm SEM $(n=8)$. ${ }^{\mathrm{a}, \mathrm{b}}$ Means with different superscripts are significantly different $(P<0.05)$.

melanocortin 4 (MCR-4), and melanocortin 5 (MCR-5) was not significantly changed $(P>0.05)$ in heat-exposed hens compared with the control (Figures 2(a), 2(c), and 2(d)). However, mRNA levels of ghrelin and cocaine- and amphetamine-regulated transcript (CART) were increased $(P<$ $0.05)$, and mRNA levels of cholecystokinin (CCK) were decreased $(P<0.05)$ in heat-exposed hens (Figures $2(\mathrm{~b})$ and $2(\mathrm{c}))$.

3.4. Expression of Feed Intake Regulatory Peptides in Gastrointestinal Tract. High ambient temperature significantly increased mRNA levels of ghrelin in the glandular stomach and jejunum $(P<0.05)$ (Figures $3(\mathrm{a})$ and $3(\mathrm{c}))$. Heat exposure significantly decreased mRNA levels of CCK in the duodenum and jejunum $(P<0.05)$ (Figures 3(b) and 3(c)). Ghrelin in the duodenum and ileum and CCK in the ileum were not affected by high ambient temperature $(P>0.05)$ (Figures 3(b) and 3(d)).

\section{Discussion}

One of the primary effects of high environmental temperatures on poultry is the reduction of feed (and energy) intake and egg production [15]. Above upper critical temperature, energy demands rise to manipulate the active cooling mechanisms in poultry. Laying hens' appetite has been shown to decrease at elevated temperatures, followed by reductions in feed intake and BW; however, the effect of high environmental temperature upon the rate of egg-laying appeared largely unrelated to feed intake [16].

Laying hens usually decrease their feed intake under high ambient temperature, mobilizing their body's energy and nitrogen stores to sustain their reproductive performance (i.e., egg production and laying rate). However, in the present study, a significant reduction was observed in the egg production and laying rate in heat-exposed laying hens (Table 2). This might be derived from the long time of heat stress. After $7 \mathrm{~d}$ of heat exposure, laying hens could not maintain their performance even by mobilization of energy and nitrogen stores. This consequence might be caused by insufficient protein deposits, as seen from the lower UA detected in the plasma of heat-exposed laying hens (Figure 1(c)). In comparison with the control group, heat-exposed birds had a small value of feed/egg ratios (Table 2), which implicated that these laying hens mobilized lots of body storage to meet the production needs. Also this increased net feed efficiency 


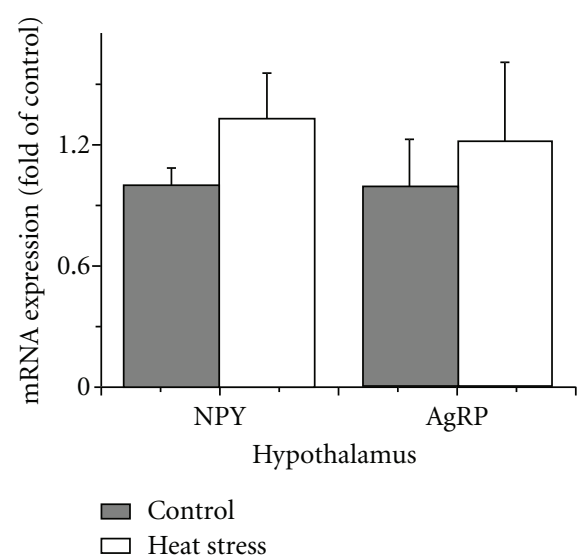

(a)

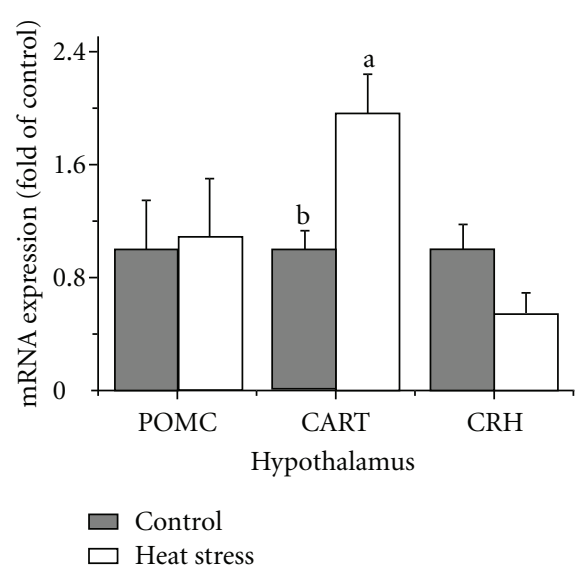

(c)

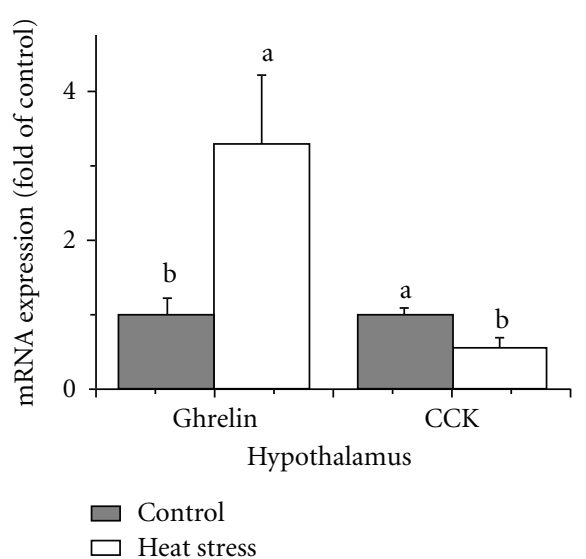

(b)

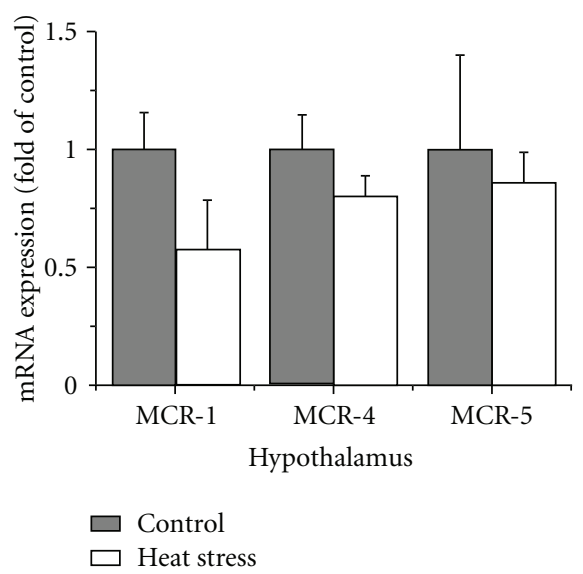

(d)

Figure 2: Effect of heat stress on gene expression of neuropeptides in the hypothalamus of laying hens. (a) Neuropeptide Y (NPY) and Agouti-Related Protein (AgRP); (b) Ghrelin and cholecystokinin (CCK); (c) Proopiomelanocortin (POMC), cocaine- and amphetamineregulated transcript (CART), and corticotropin-releasing hormone (CRH); (d) Melanocortins 1, 4, and 5 (MCR-1, MCR-4, and MCR-5). Values indicate mean $\pm \mathrm{SE}(n=6)$. ${ }^{\mathrm{a}, \mathrm{b}}$ Means with different superscripts are significantly different $(P<0.05)$.

is clearly associated with decreased heat production [17], and body heat production in poultry has been shown to decrease to alleviate the adverse effects of heat stress.

In the current study, heat exposure showed little effect on plasma parameters except plasma UA. These results might be due to the $12 \mathrm{~h}$ normal temperature recovery. Normally, heat stress is accompanied by a decrease in plasma thyroid hormones, which is associated with a decrease in the basic metabolic rate and heat production [18]. However, in the present study, exposing hens to high ambient temperatures $\left(32{ }^{\circ} \mathrm{C}\right)$ did not change the concentration of plasma $\mathrm{T}_{3}$ (Figure 1(c)). Besides the reason of temperature accumulation, another possibility was that heat-exposed hens could control their body temperature by reducing feed intake, thereby eliminating the need to change metabolic rates and plasma $\mathrm{T}_{3}$ levels. CORT is another hormone involved in the bird's metabolic rate and heat production. The effect of heat stress on poultry plasma corticosterone is complicated. Short heat stress ( 1 or $2 \mathrm{~h}$ at $42^{\circ} \mathrm{C}$ ) caused an increase in corticosterone concentration in plasma of cocks [19]. Wolfenson et al. [20] found that plasma concentration of corticosterone increased in the early stages of heat stress but recovered to the normal (even lower) levels after $4 \mathrm{~d}$. The laying hens seemed to be adapted to the high temperature and maintained the normal concentration of plasma corticosterone after several days of heat exposure. The current result was in line with the findings of Wolfenson et al. [20], which revealed that the effect of heat stress on the plasma concentration of corticosterone was related to the length of heat exposure.

In the present study, the mRNA level of CRH in the hypothalamus of heat-exposed laying hens tended to decrease $(P=0.066)$ (Figure 2). The response of CRH mRNA to repeated and chronic stress is much more complex. Depending on the stimulator, the mRNA level of CRH in the PVN may increase [21], decrease [22], or even remain unchanged [23]. It has been reported that after repeated restraint stress, a rapid adaptation of the CRH mRNA response appeared [23]. Generally speaking, heat stress showed little effect on gene expression of $\mathrm{CRH}$ in laying hens under current experimental condition.

In mammals, ghrelin is one of the most potent orexigenic feed regulatory neuropeptides in the brain [24]. However, 


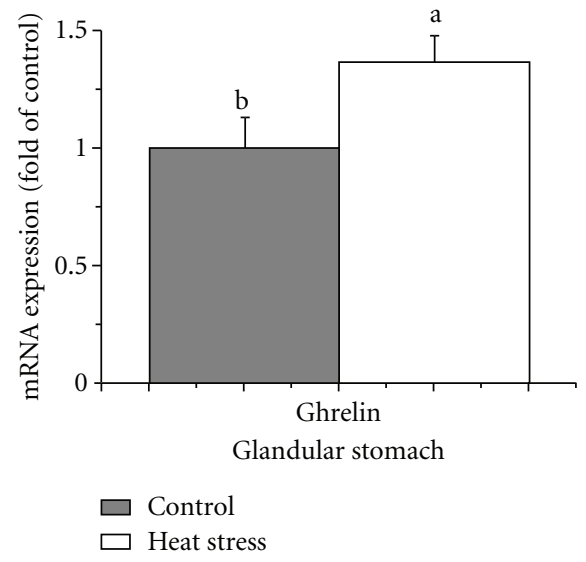

(a)

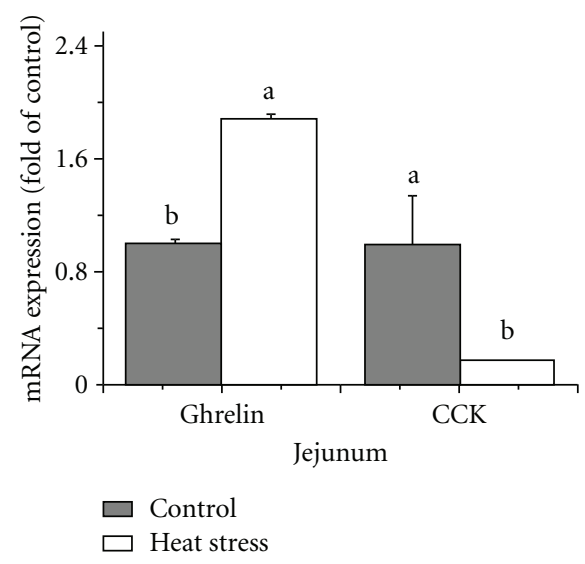

(c)

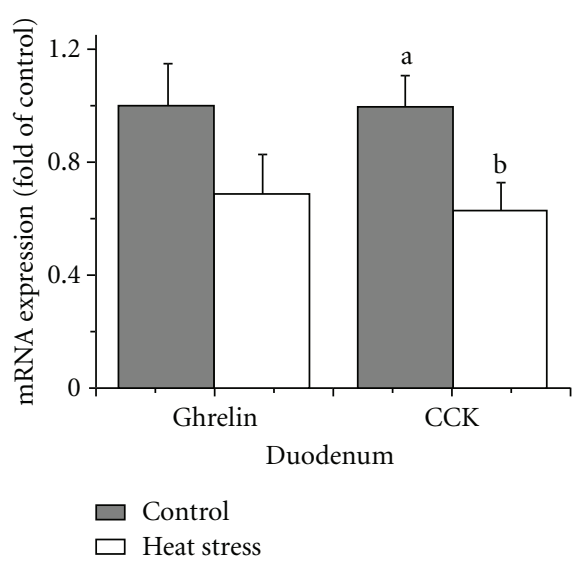

(b)

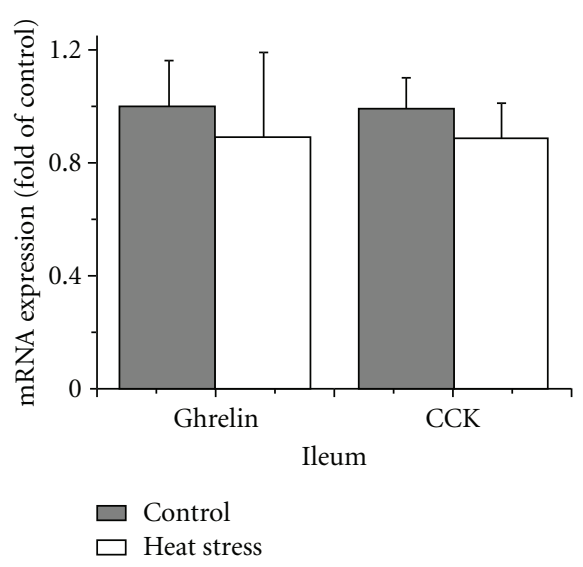

(d)

FIGURE 3: Effect of heat stress on gene expression of ghrelin and cholecystokinin (CCK) in laying hens' gastrointestinal tract. (a) Glandular stomach, (b) Duodenum, (c) Jejunum, and (d) Ileum. Values indicate mean \pm SE $(n=6)$. ${ }^{\text {a,b }}$ Means with different superscripts are significantly different $(P<0.05)$.

in chicken, ghrelin plays an inhibitory role in the regulation of feed intake when injected centrally [25]; thus, it has been classified as anorexigenic hypothalamic neuropeptides. Lutter et al. [26] demonstrated that chronic stress results in increased plasma ghrelin in humans. In the present study, heat stress resulted in the upregulation of ghrelin mRNA (Figure 2(b)) in the hypothalamus of laying hens. Ghrelin has been demonstrated to act via NPY neurons in rats [24]. However, Kaiya et al. [25] suggested that ghrelin does not activate NPY neurons in birds. In the present study, gene expression of NPY in the hypothalamus was not changed in heat-exposed hens (Figure 2(a)). In the hypothalamic arcuate nucleus (ARC), NPY neurons also express AgRP, an orexigenic peptide [24]. As shown in Figure 2(b), mRNA levels of AgRP were also not changed in the hypothalamus of heat-exposed laying hens. Therefore, more research should be done to clarify the possible roles of ghrelin on the regulation of NPY/AgRP neurons in laying hens under heat stress conditions.

There is physiological evidence indicating a role for CART peptide in the stress response [27]. In our study, the mRNA level of CART in the hypothalamus of heat-exposed hens increased compared with the control group (Figure 2(c)), which implied the pivotal role of this peptide in the regulation of feed intake in laying hens.

High ambient temperature significantly increased the expression patterns of ghrelin mRNA in the glandular stomach and jejunum (Figure 3). Peripheral injection of ghrelin in birds has an anorexigenic impact on feed intake [25]. Richards et al. [28] showed that the main sources of endogenous ghrelin in chickens are the proventriculus (glandular stomach) and brain. In the present study, expression of ghrelin mRNA was increased in both glandular stomach and hypothalamus of heat-exposed hens (Figure 3(a)). It seemed that one of the pathways for the anorexigenic effect of high ambient temperature in laying hens might be mediated by its effects on the hypothalamic and gastrointestinal ghrelin signals.

Significant downregulation of CCK gene expression was observed in the hypothalamus (Figure 2(b)), duodenum (Figure 3(b)), and jejunum (Figure 3(c)) of heat-exposed hens. CCK has been identified to be an anorexigenic gut peptide in poultry [2]. Furthermore, CCK is able to induce gut motility. Reduced central (hypothalamus) and peripheral 
(duodenum and jejunum) CCK mRNA levels in heat-exposed laying hens cause a decrease in intestine mobility and, hence, a lower passage rate, which allows intestine enzymes more time to digest nutrients. However, the information of the effect of CCK on laying hens' appetite was scarce, especially when the laying hens were under heat exposure. More research is needed to clarify its complicated physiological and biochemical functions in stressed poultry.

\section{Conclusions}

The current research was designed to explore the effect of heat stress on the regulation of appetite-associated genes in laying hens. The present results indicated that some hypothalamic and gastrointestinal tract peptides were involved in the appetite regulation in heat-exposed laying hens. The results also showed for the first time that the upregulated gene expression of ghrelin in the glandular stomach and jejunum, paralleled by its significantly increased expression in hypothalamus, might play pivotal roles in the reduction of feed intake in heat-exposed laying hens.

\section{Abbreviations}

$\begin{array}{ll}\text { UA: } & \text { Uric acid } \\ \text { Chol: } & \text { Cholesterol } \\ \text { HPA: } & \text { Hypothalamic-pituitary-adrenal } \\ \text { CRH: } & \text { Corticotropin-releasing hormone } \\ \text { T3: } & \text { Triiodothyronine } \\ \text { NEFA: } & \text { Nonesterified fatty acid } \\ \text { TG: } & \text { Triglyceride } \\ \text { GAPDH: } & \text { Glyceraldehydes-3-phosphate dehydrogenase } \\ \text { NPY: } & \text { Neuropeptide Y } \\ \text { CART: } & \text { Cocaine- and amphetamine-regulated transcript } \\ \text { POMC: } & \text { Proopiomelanocortin } \\ \text { AgRP: } & \text { Agouti-related protein } \\ \text { CCK: } & \text { Cholecystokinin } \\ \text { MCR-4: } & \text { Melanocortin } 4 \\ \text { MCR-1: } & \text { Melanocortin } 1 \\ \text { MCR-5: } & \text { Melanocortin } 5 \\ \text { MCRs: } & \text { Melanocortin receptors } \\ \text { MCH: } & \text { Melanin-concentrating hormone } \\ \text { GRF: } & \text { Growth hormone releasing factor } \\ \text { BW: } & \text { Body weight } \\ \text { CORT: } & \text { Corticosterone. }\end{array}$

\section{Authors' Contribution}

These authors contributed equally to this paper.

\section{Acknowledgments}

This paper was supported by the earmarked fund for the Modern Agro-industry Technology Research System and the National Natural Science Foundation of China (Nos. 30771573 and 31172226 ). Zhigang Song and Lei Liu contributed equally to this work.

\section{References}

[1] W. J. Kuenzel, M. M. Beck, and R. Teruyama, "Neural sites and pathways regulating food intake in birds: a comparative analysis to mammalian systems," Journal of Experimental Zoology, vol. 283, no. 4-5, pp. 348-364, 1999.

[2] M. P. Richards, R. W. Rosebrough, C. N. Coon, and J. P. McMurtry, "Feed intake regulation for the female broiler breeder: in theory and in practice," Journal of Applied Poultry Research, vol. 19, no. 2, pp. 182-193, 2010.

[3] J. R. Brobeck, "Food and temperature," Recent Progress in Hormone Research, vol. 16, pp. 439-466, 1960.

[4] C. A. Rollo, W. Grub, and J. R. Howes, "The effects of high constant environmental temperature upon caged White Leghorn pullets and hens," Annual Meeting of the American Society Agricultural Engineers, vol. 63, no. 1, pp. 401-405, 1963.

[5] W. L. Stockland and T. G. Blaylock, "The influence of ration protein level on performance of floor reared and caged reared replacement pullets," Poultry Science, vol. 53, no. 2, pp. 790800, 1974.

[6] K. Sahin, M. Onderci, N. Sahin, M. F. Gursu, F. Khachik, and O. Kucuk, "Effects of lycopene supplementation on antioxidant status, oxidative stress, performance and carcass characteristics in heat-stressed Japanese quail," Journal of Thermal Biology, vol. 31, no. 4, pp. 307-312, 2006.

[7] C. G. Payne, "Practical aspects of environmental temperature for laying hens," World's Poultry Science Journal, vol. 22, no. 2, pp. 126-139, 1966.

[8] J. S. Mckee, P. C. Harrison, and G. L. Riskowski, "Effects of supplemental ascorbic acid on the energy conversion of broiler chicks during heat stress and feed withdrawal," Poultry Science, vol. 76, no. 9, pp. 1278-1286, 1997.

[9] B. Close, K. Banister, V. Baumans et al., "Recommendations for euthanasia of experimental animals: part 2," Laboratory Animals, vol. 31, no. 1, pp. 1-32, 1997.

[10] J. S. Um and I. K. Paik, "Effects of microbial phytase supplementation on egg production, eggshell quality, and mineral retention of laying hens fed different levels of phosphorus," Poultry Science, vol. 78, no. 1, pp. 75-79, 1999.

[11] J. Simon, P. Freychet, and G. Rosselin, "Chicken insulin: radioimmunological characterization and enhanced activity in rat fat cells and liver plasma membranes," Endocrinology, vol. 95, no. 5, pp. 1439-1449, 1974.

[12] R. D. Malheiros, V. M. B. Moraes, A. Collin, E. Decuypere, and J. Buyse, "Free diet selection by broilers as influenced by dietary macronutrient ratio and corticosterone supplementation. 1. Diet selection, organ weights, and plasma metabolites," Poultry Science, vol. 82, no. 1, pp. 123-131, 2003.

[13] V. M. Darras, S. P. Kotanen, K. L. Geris, L. R. Berghman, and E. R. Kühn, "Plasma thyroid hormone levels and iodothyronine deiodinase activity following an acute glucocorticoid challenge in embryonic compared with posthatch chickens," General and Comparative Endocrinology, vol. 104, no. 2, pp. 203-212, 1996.

[14] K. J. Livak and T. D. Schmittgen, "Analysis of relative gene expression data using real-time quantitative PCR and the 2$\Delta \Delta$ CT method," Methods, vol. 25, no. 4, pp. 402-408, 2001.

[15] Y. O. Suk and K. W. Washburn, "Effects of environment on growth, efficiency of feed utilization, carcass fatness, and their association," Poultry Science, vol. 74, no. 2, pp. 285-296, 1995.

[16] I. Rozenboim, N. Mobarky, R. Heiblum et al., "The role of prolactin in reproductive failure associated with heat stress in the domestic Turkey," Biology of Reproduction, vol. 71, no. 4, pp. 1208-1213, 2004. 
[17] W. S. Pitchford, "Genetic improvement of feed efficiency of beef cattle: what lessons can be learnt from other species?" Australian Journal of Experimental Agriculture, vol. 44, no. 4-5, pp. 371-382, 2004.

[18] F. M. A. McNabb, "Thyroid hormones, their activation, degradation and effects on metabolism," Journal of Nutrition, vol. 125, no. 6, pp. 1773S-1776S, 1995.

[19] D. B. Nathan, E. D. Heller, and M. Perek, "The effect of short heat stress upon leucocyte count, plasma corticosterone level, plasma and leucocyte ascorbic acid content," British Poultry Science, vol. 17, no. 5, pp. 481-485, 1976.

[20] D. Wolfenson, D. Bachrach, M. Maman, Y. Graber, and I. Rozenboim, "Evaporative cooling of ventral regions of the skin in heat-stressed laying hens," Poultry Science, vol. 80, no. 7, pp. 958-964, 2001.

[21] F. Gómez, A. Lahmame, E. R. De Kloet, and A. Armario, "Hypothalamic-pituitary-adrenal response to chronic stress in five inbred rat strains: differential responses are mainly located at the adrenocortical level," Neuroendocrinology, vol. 63, no. 4, pp. 327-337, 1996.

[22] M. S. Harbuz, R. G. Rees, D. Eckland, D. S. Jessop, D. Brewerton, and S. L. Lightman, "Paradoxical responses of hypothalamic corticotropin-releasing factor (CRF) messenger ribonucleic acid (mRNA) and CRF-41 peptide and adenohypophysial proopiomelanocortin mRNA during chronic inflammatory stress," Endocrinology, vol. 130, no. 3, pp. 1394-1400, 1992.

[23] S. L. Lightman and M. S. Harbuz, "Expression of corticotropin-releasing factor mRNA in response to stress," Ciba Foundation Symposium, vol. 172, pp. 173-187, 1993.

[24] M. Goto, H. Arima, M. Watanabe et al., "Ghrelin increases neuropeptide $\mathrm{Y}$ and agouti-related peptide gene expression in the arcuate nucleus in rat hypothalamic organotypic cultures," Endocrinology, vol. 147, no. 11, pp. 5102-5109, 2006.

[25] H. Kaiya, M. Furuse, M. Miyazato, and K. Kangawa, "Current knowledge of the roles of ghrelin in regulating food intake and energy balance in birds," General and Comparative Endocrinology, vol. 163, no. 1-2, pp. 33-38, 2009.

[26] M. Lutter, I. Sakata, S. Osborne-Lawrence et al., "The orexigenic hormone ghrelin defends against depressive symptoms of chronic stress," Nature Neuroscience, vol. 11, no. 7, pp. 752753, 2008.

[27] O. Gozen, B. Balkan, G. Yararbas, E. O. Koylu, M. J. Kuhar, and S. Pogun, "Sex differences in the regulation of cocaine and amphetamine-regulated transcript expression in hypothalamic nuclei of rats by forced swim stress," Synapse, vol. 61, no. 7, pp. 561-568, 2007.

[28] M. P. Richards, S. M. Poch, and J. P. McMurtry, "Characterization of turkey and chicken ghrelin genes, and regulation of ghrelin and ghrelin receptor mRNA levels in broiler chickens," General and Comparative Endocrinology, vol. 145, no. 3, pp. 298-310, 2006. 

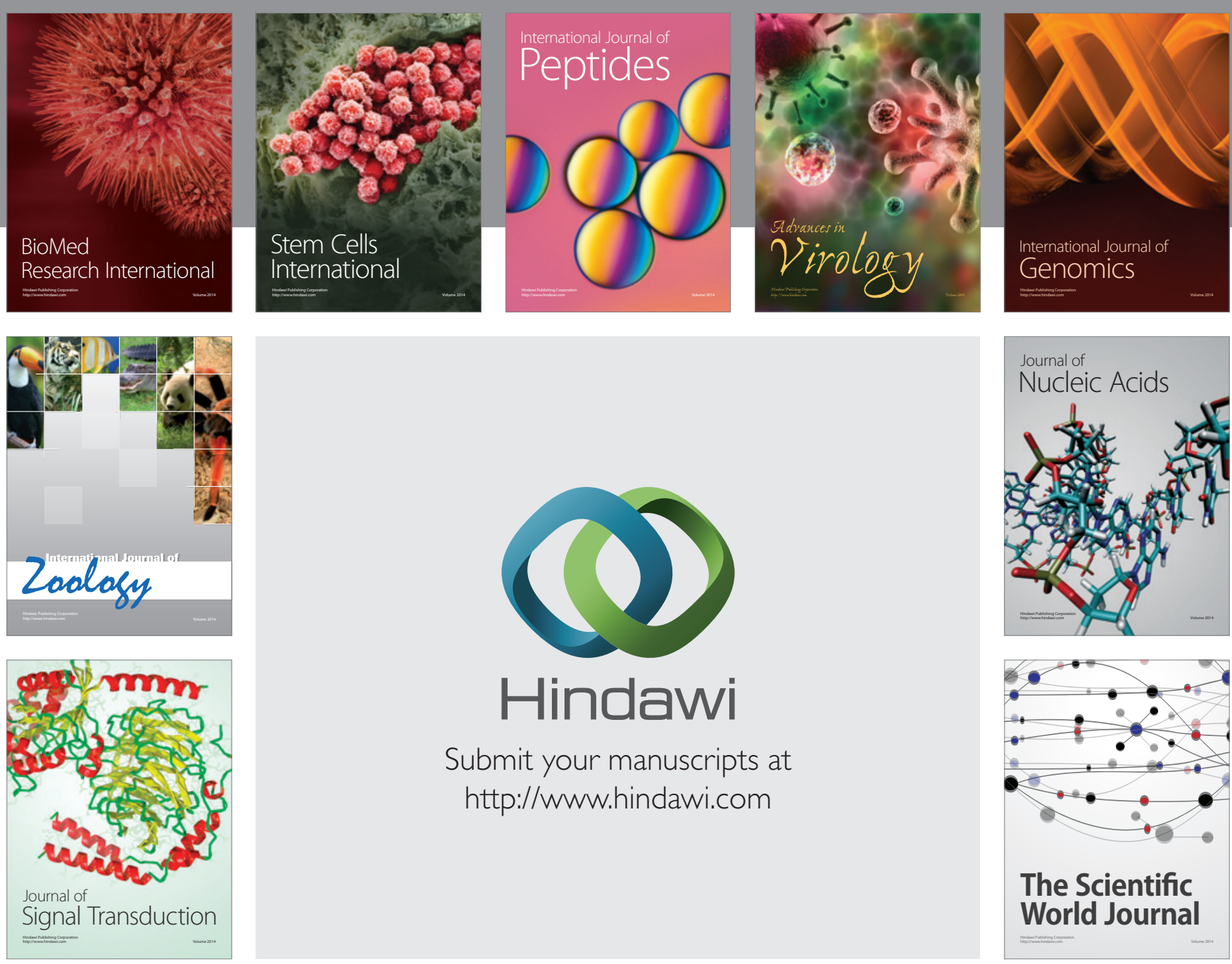

Submit your manuscripts at

http://www.hindawi.com
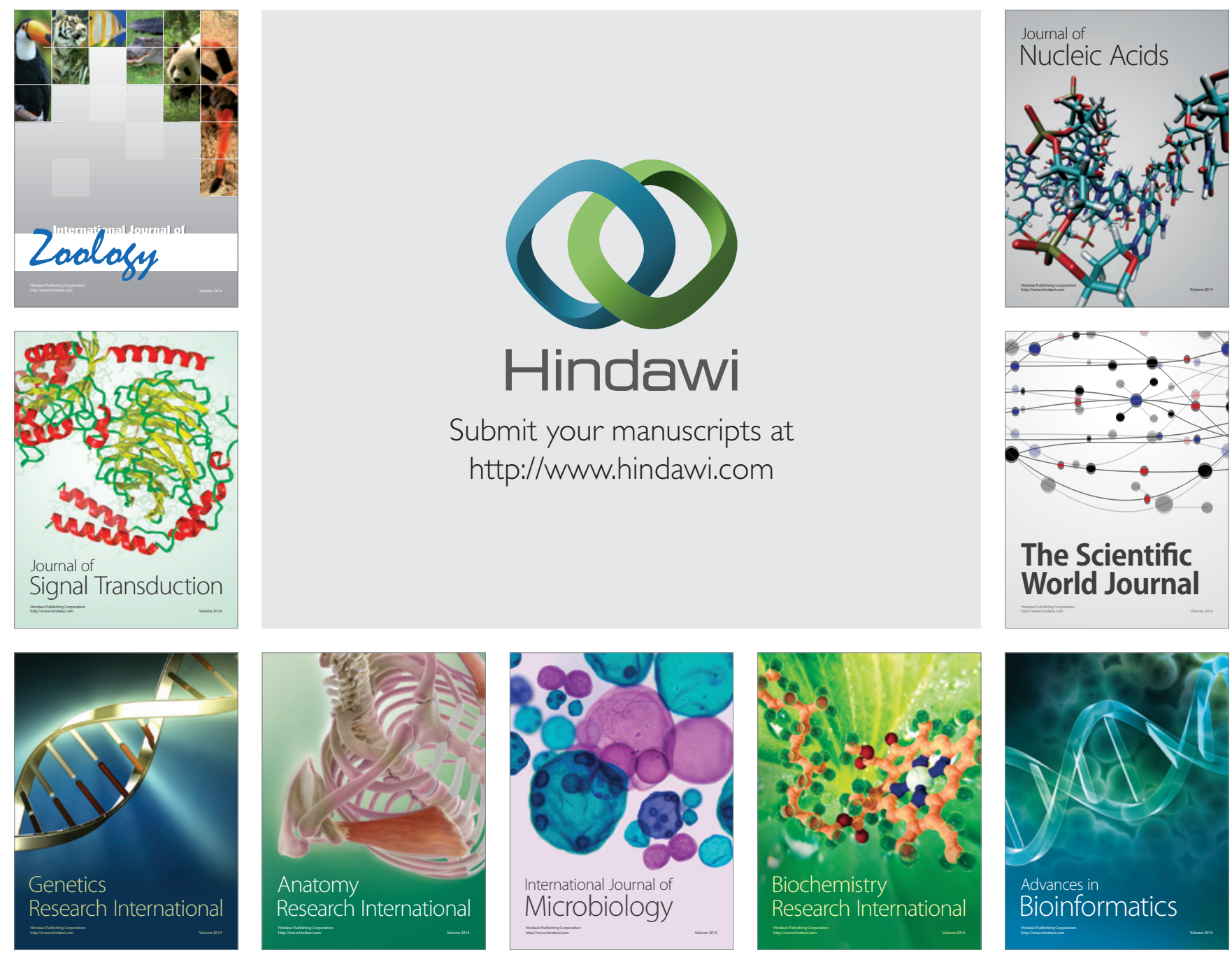

The Scientific World Journal
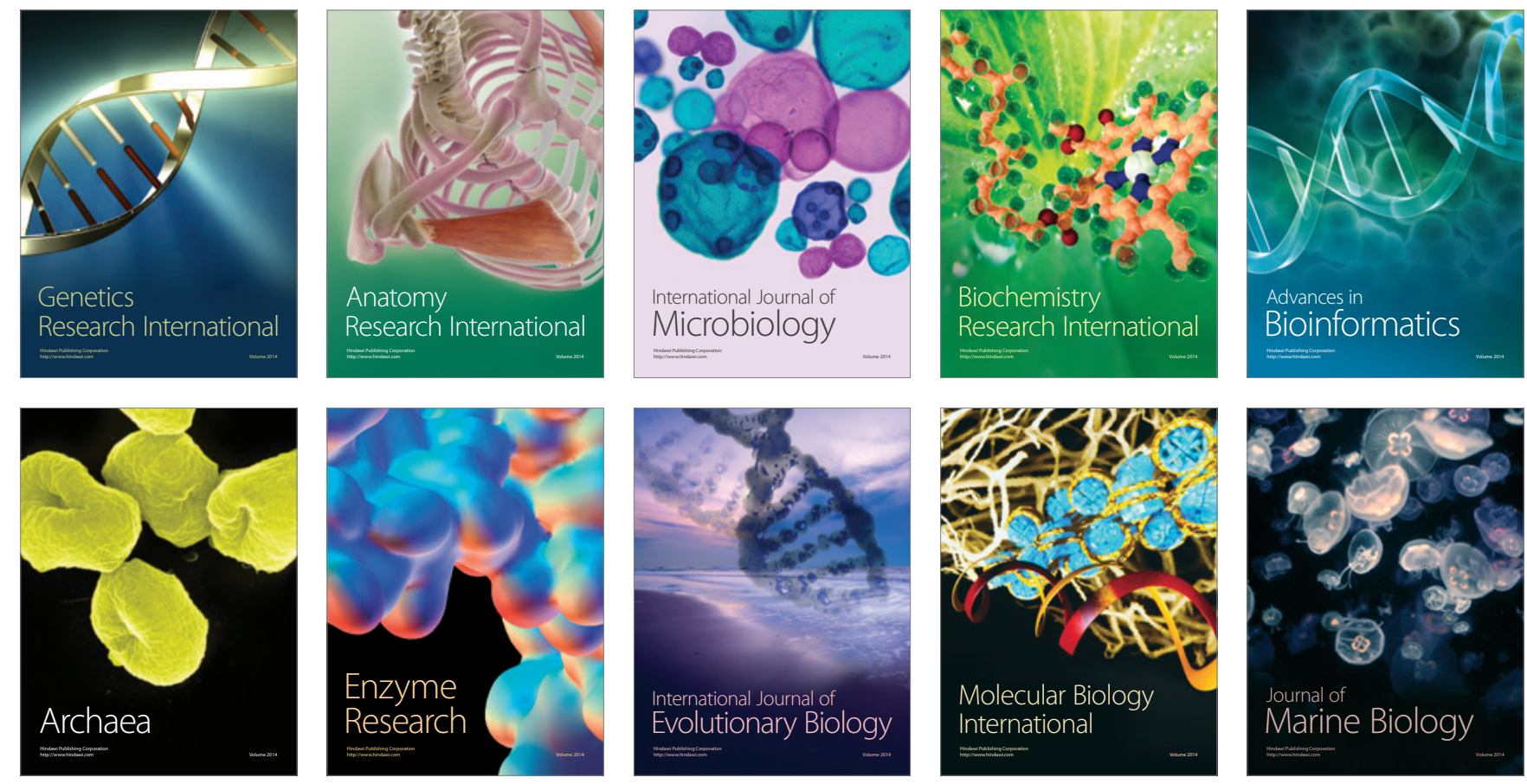